\title{
The Expression of Nicotinic Acetylcholine Receptors by PC12 Cells Treated with NGF
}

\author{
Scott W. Rogers, ${ }^{1,2}$ Allan Mandelzys, ${ }^{3}$ Evan S. Deneris, ${ }^{4}$ Ellis Cooper, ${ }^{3}$ and Stephen Heinemann ${ }^{2}$ \\ 'Department of Pharmacology and Neuroscience Program, University of Colorado Health Sciences Center, Denver, \\ Colorado 80262, 2Molecular Neurobiology Laboratory, The Salk Institute for Biological Studies, La Jolla, California 92037, \\ ${ }^{3}$ Department of Physiology, McGill University, Montréal, Québec H3G1YG, Canada, and ${ }^{4}$ Department of Neuroscience, \\ Case Western Reserve University, Cleveland, Ohio 44106
}

\begin{abstract}
The expression of neuronal nicotinic ACh receptors (nAChRs) and the subunits that compose these receptors by PC12 cells exposed to NGF has been studied. The analysis of total RNA reveals that the neuronal nAChR subunits $\alpha_{3}, \alpha_{5}, \beta_{2}, \beta_{3}$, and $\beta_{4}$, but not $\alpha_{2}$ and $\alpha_{4}$, are expressed in our PC12 cells. Within $48 \mathrm{hr}$ of adding NGF to cultures, the RNA corresponding to $\alpha_{3}, \alpha_{5}, \beta_{3}$, and $\beta_{4}$ is decreased, but the $\beta_{2}$ RNA increases for up to $6 \mathrm{~d}$ after NGF treatment. To determine the influence of NGF treatment on subunit protein expression, subunitspecific antisera were prepared. Immunocytochemistry detected antigen for $\alpha_{3}, \alpha_{5}, \beta_{2}, \beta_{3}$, and $\beta_{4}$ (but not $\alpha_{2}$ and $\alpha_{4}$ ) in both NGF-treated and nontreated PC12 cells. The expression of nAChR subunit proteins, as measured by direct binding of antibodies to PC12 cells, does not change subsequent to $6 \mathrm{~d}$ of treatment with NGF. Whole-cell recording of PC12 cells shows that both the individual cell current density and response to the agonist cytisine were not altered after 5-7 d in NGF. However, the number of cells exhibiting detectable ACh-induced currents doubled. These results indicate that NGF increases the number of PC12 cells expressing AChsensitive nAChR currents but the activation is not the result of altering the amounts of individual nAChR subunit proteins. These data, taken together with the decrease in most nAChR subunit RNAs (except $\beta_{2}$ ), suggest that NGF regulation of nAChRs may be through a posttranscriptional mechanism.
\end{abstract}

Neurotransmitter receptors play a central role in regulating the capacity of neurons to communicate, and they have the intriguing ability to be modified commensurate with their use. Our interest is to investigate the mechanisms that regulate the expression of neuronal nicotinic ACh receptors (nAChRs) in the mammalian nervous system. As a model system, we have employed PC12 cells, a rat pheochromocytoma cell line (Grecne and Tischler, 1982) that has been used extensively to study NGF-induced neuronal differentiation and altered $n A C h R$ func-

\footnotetext{
Received Feb. 26, 1992; revised May 28, 1992; accepted June 5, 1992.

We thank Drs. Jim Boulter, Robert Duvoisin, Lorise Gahring, and David Johnson for their efforts that contributed to the completion of these studies. This work was supported by an NIH postdoctoral fellowship and NIH grant NS30990R29-01 to S.W.R.; grants from the NIH, Muscular Dystrophy Association, and University of California Tobacco-Related Research Program to S.H.; Grant 4715 from the Northeast Ohio affiliate of the American Heart Association to E.S.D.; and funding from the MRC of Canada to E.C.

Correspondence should be addressed to Scott W. Rogers, Department of Pharmacology, C-236, University of Colorado Health Sciences Center, 4200 East Ninth Avenue, Denver, CO 80262.

Copyright (C) 1992 Society for Neuroscience $0270-6474 / 92 / 124611-13 \$ 05.00 / 0$
}

tion. PC12 cells have the advantage of not requiring NGF for survival in culture, but upon addition of NGF they extend neurite-like processes and acquire many biochemical and physiological properties that are typical of autonomic neurons. Notably, the addition of NGF to PC12 cells correlates with an increase in the electrical excitability of these cells to ACh (Dichter et al., 1977; Patrick and Stallcup, 1977; Ifune and Steinbach, 1990), a process that is mediated through the altered expression or function of nAChRs.

The application of methods of molecular cloning has revealed an extended family of neuronal-specific nAChR subunits (Boulter et al., 1986, 1990; Deneris et al., 1988) that are expressed throughout the PNS and CNS (for review, see Deneris et al., 1991) and in PC12 cells (Boulter et al., 1986, 1990; Deneris et al., 1988). The mammalian neuronal nAChR family consists of at least four $\alpha$-like subunits, $\alpha_{2}$ (Wada et al., 1988), $\alpha_{3}$ (Boulter et al., 1986), $\alpha_{4}$ (Goldman et al., 1987), and $\alpha_{5}$ (Boulter et al., 1990 ), and three $\beta$-like subunits, $\beta_{2}$ (Deneris et al., 1988), $\beta_{3}$ (Deneris et al., 1989), and $\beta_{4}$ (Duvoisin et al., 1989). The pairwise expression of an $\alpha$-and a $\beta$-subunit in various combinations in Xenopus oocytes has shown that numerous receptor subtypes are created that can be distinguished by both their pharmacology and single-channel properties (Boulter et al., 1987; Duvoisin et al., 1989; Papke et al., 1989, 1991; Luetje et al., 1990; Luetje and Patrick, 1991). Since the expression of RNA for each subunit in the mammalian CNS has been shown to be unique but overlapping among the respective subunits (Wada et al., 1989), there exists the potential for substantial complexity in the regulation, structure, and function of neuronal nAChRs.

PC12 cells have been reported to express RNA for multiple nAChR subunits including $\alpha_{3}, \alpha_{5}, \beta_{2}$, and $\beta_{4}$ (Boulter et al., 1990). Lindstrom and colleagues (Whiting et al., 1987) have observed that upon addition of NGF to PC12 cells, the surface binding sites for the monoclonal antibody (mAb) 270 , which is thought to bind to the $\beta_{2}$ subunit (Whiting et al., 1991), increased by six- to sevenfold concomitant with a sixfold induction in carbachol-stimulated ${ }^{86} \mathrm{Rb}$ flux. However, the simultaneous measurement of the regulation of nAChR subunit RNA, subunit protein, and receptor function in $\mathrm{PC} 12$ cells subsequent to exposure to NGF has not been reported. In this study, we examine by Northern blot and RNase protection assays the effect NGF has on the expression of the respective $n A C h R$ subunit RNAs and the effect of NGF on the expression of nAChR subunit protein as measured using subunit-specific antisera developed for this study, and the functional expression of nAChRs is quantified using electrophysiological techniques. 


\section{Materials and Methods}

PC12 cell culture. PC12 cells (obtained from I. Verma, Salk Institute) were cultured in Dulbecco's modified Eagle's medium [low glucose formulation, GIBCO/Bethesda Research Labs (BRL)] containing $10 \%$ fetal bovine serum (HYCLONE) and 5\% heat-inactivated horse serum (HYCLONE). The heat inactivation of the horse serum was conducted for $1 \mathrm{hr}$ at $56^{\circ} \mathrm{C}$. Cells were grown in a humidified $7.5 \% \mathrm{CO}_{2}$ atmosphere at $37^{\circ} \mathrm{C}$. At confluency, the cells were dislodged from the culture dish by shaking or trituration with medium from a pipette, and a portion of these cells were replated into new culture dishes. This process selects against flat cells that adhere tightly to the dish and are not responsive to NGF (see Results). Trypsin and EDTA were avoided. For experiments, PC12 cells that were used in immunocytochemistry and radiolabel binding assays were cultured on gelatin-treated culture surfaces.

Analysis of $R N A$. RNA was isolated from 1-5 $\times 10^{6} \mathrm{PC} 12$ cells by the method of Chomczynski and Sacchi (1987). The transfer of fractionated RNA to Nytran (Schleicher and Schuell) and hybridization of Northern blots were conducted as described by Boulter et al. (1990) except that saline-sodium citrate was substituted for saline-sodium phosphate-EDTA. Random primed probes were prepared from the fulllength cDNA of each neuronal $n A C h R$ subunit using the Amersham random-prime kit. Probes typically had a specific activity of $0.5-1 \times$ $10^{9} \mathrm{cpm} / \mu \mathrm{g}$.

RNase protection assays were performed as described by Krieg and Melton (1987). Antisense probes were synthesized using SP6 or T7 polymerase from the pGEM or pSP64 vector (Promega) containing subcloned portions of the cDNA encoding each neuronal nAChR subunit. The following regions for each cDNA were used: $\alpha_{2}$ [HYP16(9); Wada et al., 1988], nucleotides 1748-1932, protected length 184 bases; $\alpha_{3}$ [pPCAlpha 48E(4); Boulter et al., 1986], nucleotides 1557-1815, protected length 258; $\alpha_{4}$ [pHYAlpha 231E(1); Goldman et al., 1987], nucleotides $0-553$, protected length 553 bases; $\alpha_{5}$ (Alpha 5; Boulter et al., 1990), nucleotides 1160-1639, protected length 479 bases; $\beta_{2}$ (pGPR 49; Deneris et al., 1988), nucleotides 1617-2195, protected length 578 bases; $\beta_{3}$ (pESD7; Deneris et al., 1989), nucleotides 568-1021, protected length 453 bases; $\beta_{4}$ (p7.PC13; Duvoison et al., 1989), nucleotides 2049-2460, protected length 411 bases.

Constructs and bacterial overexpression. Complementary DNA clones encoding subunits of neuronal nicotinic acetylcholine receptor subunits were used for constructs. Portions of the cDNA encoding the amino acids (numbered from the initiation methionine) of subunits $\alpha_{2}$ (371511 ; Wada et al., 1988), $\alpha_{3}$ (284-470; Boulter et al., 1986), $\alpha_{4-1}$ (461594; Goldman et al., 1987), $\alpha_{5},\left(345-452\right.$; Boulter et al., 1990), $\beta_{2}(394$ 503; Deneris et al., 1988a), $\beta_{3}\left(330-464\right.$; Deneris et al., 1989), and $\beta_{4}$ (328-426; Duvoisin et al., 1989) were removed by restriction digest and subcloned in the appropriate pATH vector (trpE bacterial overproduction system; Dieckmann and Tzagolott, 1985). The host strain was Escherichia coli strain HB101. Overexpression of fusion proteins was done as described previously (Rogers et al., 1991a,b).

Gel electrophoresis and immunization. Overproduced proteins were fractionated using sodium dodecyl sulfate polyacrylamide gel electrophoresis (SDS-PAGE), and protein bands were visualized by soaking the gel in ice-cold $0.25 \mathrm{M} \mathrm{KCl}$ for $1 \mathrm{hr}$, and then were cut from the gel (see Rogers et al., 1991a,b). The gel fragments were macerated, emulsified in complete Freund's adjuvant (GIBCO/BRL), and injected subcutaneously into young New Zealand White rabbits. Each rabbit received $200-400 \mu \mathrm{g}$ of protein. Three weeks later, rabbits were boosted with $200-400 \mu \mathrm{g}$ of antigen as above except emulsification was in incomplete Freund's adjuvant (GIBCO/BRL). Serum was collected $12 \mathrm{~d}$ later. Subsequent boosts and sera collections were done at 1 month intervals.

Antibody testing. Specificity of the antisera was tested using Western blot and ELISA analysis. For Western blot analysis, overproduced proteins were separated by SDS-PAGE and transferred to nitrocellulose filters (Kyhse-Andersen, 1984). Filters were then blocked in PBS containing 5\% Carnation nonfat dry milk (Blotto) for $1 \mathrm{hr}$ at room temperature. To each blot was added rabbit serum (either complete or absorbed with proteins from bacteria containing the pATH 1 vector) in Blotto $(1: 3000)$. After $14 \mathrm{hr}$ at $4^{\circ} \mathrm{C}$, blots were washed in three changes of Blotto. Goat anti-rabbit alkaline phosphatase-conjugated second antibody was added in Blotto (1:1000; Cappel) for $2 \mathrm{hr}$ at room temperature. Blots were subsequently rinsed in developing buffer [ $50 \mathrm{~mm}$ sodium carbonate ( $\mathrm{pH} \mathrm{9.5),2} \mathrm{mM} \mathrm{MgCl}_{2}$ ] and then visualized in developing buffer containing $0.1 \mathrm{mg} / \mathrm{ml} p$-nitro blue tetrazolium chloride, $0.05 \mathrm{mg}$ / $\mathrm{ml}$ 5-bromo-4-chloro-3-indolyl phosphate. The reaction was stopped with PBS containing 1 mM EDTA.

ELISA assays were conducted to determine the serum titer and further determine the amount of cross-reactivity between the antisera produced in this study. Overproduced proteins were dissolved in freshly prepared $8 \mathrm{M}$ urea $(10 \mathrm{ml}$ per gram of protein) at room temperature for $1 \mathrm{hr}$. The solution was clarified by centrifugation and the supernatant diluted 1 : 10 by the slow addition of a solution of $50 \mathrm{~mm} \mathrm{KCl}$ and $50 \mathrm{~mm} \mathrm{NaCl}$ (pH 10.5). After an additional hour of stirring at room temperature, the solution was brought to $\mathrm{pH} 8$ with $1 \mathrm{~N} \mathrm{HCl}$ and repeatedly dialyzed against $10 \mathrm{~mm} \mathrm{NaCl}$ in $10 \mathrm{~mm}$ sodium phosphate buffer (pH 7.2) at $4^{\circ} \mathrm{C}$. The concentration of soluble protein was then measured by standard Biuret assay (Bio-Rad). Immulon microtiter plates were then prepared. Solubilized antigen ( $5 \mu \mathrm{g} /$ well) in $100 \mu \mathrm{l}$ of coupling buffer ( 50 mM Tris, $\mathrm{pH} 9.5$ ) was added to each well for $14 \mathrm{hr}$ at $4^{\circ} \mathrm{C}$. Wells were thoroughly washed with PBS and blocked with blocking PBS (PBS containing 5\% heat-inactivated calf serum and $0.05 \%$ Tween) for $45 \mathrm{~min}$ at room temperature. Rabbit serum at various dilutions (e.g., 1:50, 1: $150,1: 450$, etc.) in blocking PBS was then added, and dishes were incubated for $4 \mathrm{hr}$ at room temperature or overnight at $4^{\circ} \mathrm{C}$. Plates were washed five times with blocking PBS before adding goat anti-rabbit alkaline phosphatase-coupled second antibody $(1: 2000)$ for $45 \mathrm{~min}$ at room temperature. Plates were again washed with PBS and developed with $p$-nitrophenyl phosphate $(1 \mathrm{mg} / \mathrm{ml})$ in $50 \mathrm{~mm}$ potassium carbonate and $1 \mathrm{~mm}$ magnesium chloride (pH 9.8) for approximately $15 \mathrm{~min}$ at room temperature. The reaction was stopped with $50 \mu 1 /$ well of $0.3 \mathrm{~N}$ $\mathrm{NaOH}$ and plates were scanned on a Teritek multiscan ELISA reader at $410 \mathrm{~nm}$.

Measurement of nAChR subunit protein. The detection of neuronal nAChR subunits was measured by direct binding of antibodies to PC12 cells. PC1 2 cells were distributed to gelatin-coated six-well culture dishes $\left(10^{5}\right.$ cells/well). PC12 cells were washed gently and fixed with freshly prepared $2 \%$ paraformaldehyde (Electron Microscopy Sciences) in 0.1

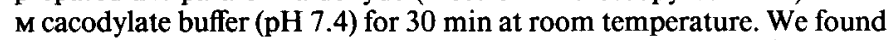
the purity and concentration of paraformaldehyde to be crucial to obtaining reproducible results. Concentrations of less than $1.5 \%$ or greater than $2 \%$ resulted in diminished immunoreactivity (not shown). The fixative was removed, and the cells were washed gently with PBS, and then permeabilized using blocking PBS (PBS with either $1 \%$ heat-inactivated calf serum or normal goat serum; GIBCO) containing $0.3 \%$ Triton X-100 (Pharmacia) for $30 \mathrm{~min}$ at room temperature. Cells were washed in blocking PBS, and rabbit antiserum diluted in blocking PBS was then added to the cells for $4 \mathrm{hr}$ at room temperature or overnight at $4^{\circ} \mathrm{C}$. To minimize background, antisera were first adsorbed against Rat 2 fibroblasts. Rat 2 fibroblasts were grown to confluency in 150 $\mathrm{mm}$ culture dishes as described previously (Rogers et al., 1991a), fixed, permeabilized, and placed in blocking PBS as described above for $\mathrm{PC} 12$ cells. The preimmune or primary antiserum was then diluted to the working concentration in blocking PBS (final volume of approximately $5 \mathrm{ml}$ ) and then adsorbed over the monolayer of Rat 2 cells for $4 \mathrm{hr}$ at room temperature. This preparation was then used immediately for direct binding or immunocytochemistry (see below). The cells were washed three times in blocking PBS and then rocked in a fourth change of blocking PBS for 30-60 min at room temperature. Blocking PBS containing radioiodinated secondary antibody was then added to the cells for $1 \mathrm{hr}$ at room temperature. Cells were gently washed in four changes of PBS, the well was removed from the culture dish using a hot wire, and the total remaining radioiodine was quantitated by gamma counting using a Beckman Gamma 300 counter at 30\% efficiency.

Radioiodination of goat anti-rabbit second antibody (Cappel) was done by the lactoperoxidase method as described by Harlow and Lane (1988). Typical specific activities were $10^{6} \mathrm{cpm} / \mu \mathrm{g}$, which corresponds to a substitution ratio of approximately $0.5 \mathrm{~mol}$ of ${ }^{125} \mathrm{I} / \mathrm{mol}$ of protein. The specific binding was calculated as the binding of either $\alpha_{2}$ (control), $\alpha_{3}, \alpha_{5}, \beta_{2}$, or $\beta_{1}$ antiserum minus the respective preimmune serum per cell. The value for PC12 cells not treated with NGF was set to 100 , and the relative proportion of binding to this value was calculated for PC12 cells treated with NGF. Measurements were made in duplicate for each experiment.

Immunocytochemistry. PC1 2 cells were fixed, permeabilized, and reacted with the designated antisera as described above. The secondary antibody (alkaline phosphatase-conjugated goat anti-rabbit, Cappel) was then added to the cells for $1 \mathrm{hr}$ at room temperature. The cells were washed with three changes of PBS and twice with $50 \mathrm{~mm}$ sodium carbonate buffer containing $2 \mathrm{~mm}$ magnesium chloride $(\mathrm{pH} 9.5)$, and the 

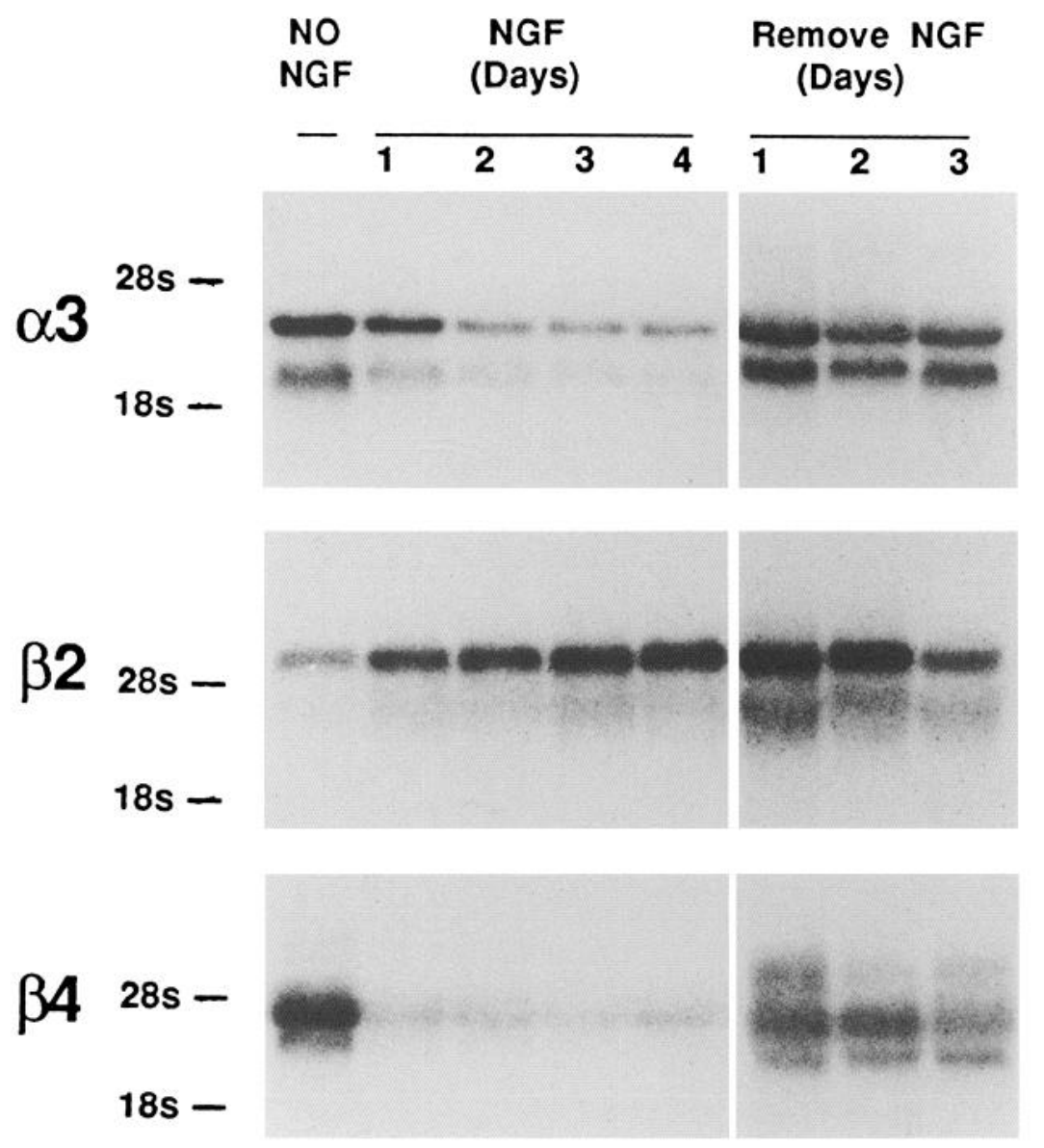

Figure 1. Northern blot hybridization analysis of total RNA from PC12 cells. Total RNA was isolated from 1-5 $\times$ $10^{6} \mathrm{PC} 12$ cells that were either not treated with NGF, treated for $1-4 \mathrm{~d}$ with NGF, or treated with NGF for $4 \mathrm{~d}$ and then returned to NGF-free culture medium for 1-3 d. Twenty micrograms of total RNA for each sample were electrophoresed through $1 \%$ agarose gels containing formaldehyde, transferred to Nytran blotting membrane, and then probed with full-length cDNA randomprimed probes for each subunit as described in Materials and Methods. The exposure was for $14 \mathrm{hr}$ at $-70^{\circ} \mathrm{C}$, and the locations of the $28 \mathrm{~s}$ and $18 \mathrm{~s}$ ribosomal RNA are indicated. alkaline phosphatase was visualized by developing the cells at room temperature in the same buffer with freshly added nitro blue tetrazolium $(1 \mathrm{mg} / \mathrm{ml})$ and 5-bromo-4-chloro-3-indolyl phosphate $(0.5 \mathrm{mg} / \mathrm{ml})$. Development was usually for $30-60 \mathrm{~min}$, with fresh developing solution added every $15 \mathrm{~min}$. To stop the reaction, PBS supplemented to $2 \mathrm{~mm}$ EDTA was added. Successful permeabilization of PC12 cells was monitored in cells in adjacent wells with fluoresceinated anti-tubulin antibody (Boehringer Mannheim; not shown).

DNA synthesis by PC12 cells was visualized using immunocytochemistry for the incorporation of 5-bromo-2-deoxyuridine (BUdR). PC1 2 cells were grown without NGF and in the presence of NGF for $2-5 \mathrm{~d}$. For the final $24 \mathrm{hr}$ of culture, BUdR ( $40 \mu \mathrm{M}$ final) was added, and cells were rinsed with PBS, and fixed with $95 \%$ ethanol, $5 \%$ acetic acid for $30 \mathrm{~min}$ at room temperature. The cells were rinsed with distilled water and the DNA was denatured with $2 \mathrm{~N} \mathrm{HCl}$ for $30 \mathrm{~min}$. The cells were rinsed with PBS, placed in blocking PBS containing mouse antiBUdR (1:100; Becton-Dickinson) for $30 \mathrm{~min}$, rinsed with PBS, placed in blocking PBS containing goat anti-mouse alkaline phosphatase-conjugated secondary antibody (Cappel), and visualized as described above.

Electrophysiology. Sensitivity of $\mathrm{PC} 12$ cells to ACh was measured electrophysiologically using whole-cell patch-clamp techniques (Hamill et al., 1981). All recordings were done with a List EPC-7 amplifier at $22-24^{\circ} \mathrm{C}$. The recording electrodes typically had resistances of $2-6 \mathrm{M} \Omega$, and the current signal balanced to zero. During the experiments, membrane currents and voltages were filtered at $3 \mathrm{kHz}$, digitized at $44 \mathrm{kHz}$ by a pulse code modulation unit (PCM 701, Sony Corp.), and stored on a Beta videocassette recorder. Round PC12 cells with clear nuclei were selected at random. In pilot experiments, we found that flat cells that adhered tightly to the culture surface were insensitive to $\mathrm{ACh}$, and these were not examined further (not shown). For most PC12 cells, the membrane potential was held at two potentials, $-50 \mathrm{mV}$ and -100 $\mathrm{mV}$, while ACh (ACh iodide, Sigma Chemical Co.) was applied to the cell body, as well as the proximal processes of the NGF-treated cells.

To measure the overall $\mathrm{ACh}$ current density of each $\mathrm{PC} 12$ cell, we applied the drug by pressure ejection from relatively large-tipped pi- pettes $(10-20 \mu \mathrm{m})$, positioned at an appropriate distance $(30-40 \mu \mathrm{m})$ from the PC12 cell, so that upon application of light pressure (usually 20-30 kPa) we could perfuse a large area (see Mandelzys et al., 1990). The cultures were continuously perfused at the rate of $1 \mathrm{ml} / \mathrm{min}$ with extracellular solution (see below) to ensure that the drug did not accumulate during the experiment. The ACh pipettes were filled with $50 \mu \mathrm{M}$ $\mathrm{ACh}$ dissolved in the extracellular solution. This concentration of $\mathrm{ACh}$ was chosen to ensure that we could detect cells with ACh-gated currents but avoid agonist-induced desensitization. The extracellular solution was composed of $140 \mathrm{~mm} \mathrm{NaCl}, 5.4 \mathrm{~mm} \mathrm{KCl}, 2.8 \mathrm{~mm} \mathrm{CaCl}_{2}, 0.18 \mathrm{~mm}$ $\mathrm{MgCl}_{2}, 10 \mathrm{~mm}$ HEPES, $5.6 \mathrm{~mm}$ glucose, $2 \mathrm{~mm}$ glutamine, $30 \mathrm{U} / \mathrm{ml}$ penicillin, and $30 \mu \mathrm{g} / \mathrm{ml}$ streptomycin. The intracellular solution consisted of $80 \mathrm{~mm} \mathrm{KF}, 60 \mathrm{~mm} \mathrm{~K}$-acetate, $5 \mathrm{~mm} \mathrm{NaCl}, 1 \mathrm{~mm} \mathrm{MgCl}_{2}, 10$ mм EGTA, and 10 mм HEPES. All solutions were adjusted to $\mathrm{pH} 7.2$ 7.4 with $\mathrm{NaOH}$ for the extracellular solution and $\mathrm{KOH}$ for the intracellular solution. The limit of resolution in this study was determined to be $5-10 \mathrm{pA}$, which is equivalent to three to five receptors open simultaneously. Since the average cell capacitance is approximately 30 $\mathrm{pF}$, our limit of detection is $0.3 \mathrm{pA} / \mathrm{pF}$. $\mathrm{PC} 12$ cells with $\mathrm{ACh}$-gated currents below this value were grouped as insensitive.

To determine the relationship between currents evoked by $\mathrm{ACh}$ and those evoked by cytisine (Aldrich Chemical Co.), we constructed doublebarreled pipettes so that the tip of each barrel was fused side by side; each tip was 15-20 $\mu \mathrm{m}$. One barrel contained $50 \mu \mathrm{M} \mathrm{ACh}$, and the other barrel contained $50 \mu \mathrm{M}$ cytisine. All ACh currents are normalized to cell capacitance by integrating the capacity current evoked by a $5 \mathrm{mV}$ hyperpolarizing voltage step from a holding potential of $-50 \mathrm{mV}$. Untreated PC12 cells had capacitances that ranged from $13 \mathrm{pF}$ to $18 \mathrm{pF}$, whereas NGF-treated $\mathrm{PCl} 2$ cells had capacitances ranging from $22 \mathrm{pF}$ to $30 \mathrm{pF}$. The distributions of ACh current densities represent values obtained in response to $50 \mu \mathrm{M}$ ACh at a holding potential of $-50 \mathrm{mV}$ and were plotted on a log scale to cover the wide range of values (from $0.3 \mathrm{pA} / \mathrm{pF}$ to $28.1 \mathrm{pA} / \mathrm{pF}$ ) that exist on different PC12 cells. The zero column in each distribution reflects the proportion of neurons in which there was no detectable response. We used the Mann-Whitney $U$ test 


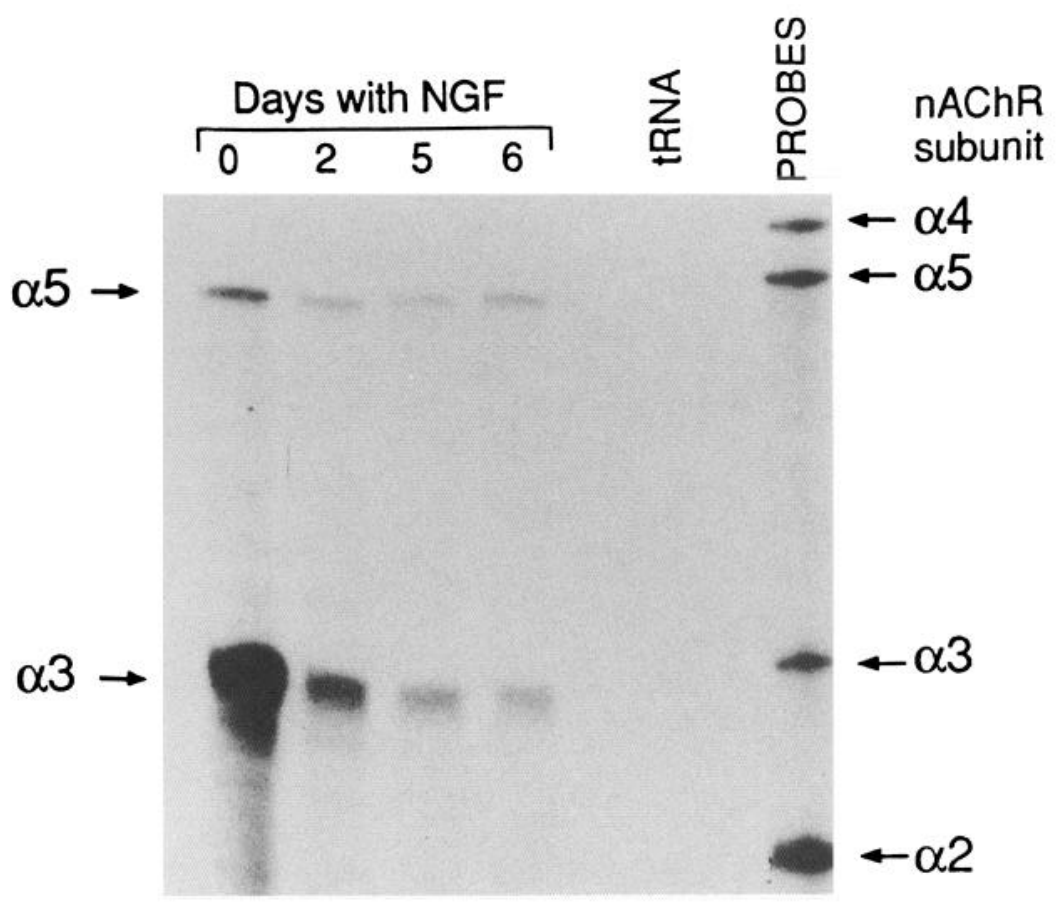

Figure 2 RNase protection of $\mathrm{nAChR}$ subunits from total RNA prepared from PC12 cells treated with NGF. Total RNA from PC12 cells treated with NGF for the indicated time period was prepared and analyzed with subunit-specific probes as described in Materials and Methods. Protected transcripts were observed for nAChR subunits $\alpha_{3}, \alpha_{5}, \beta_{2}$, $\beta_{3}$, and $\beta_{4}$, but not $\alpha_{2}$ or $\alpha_{4}$.

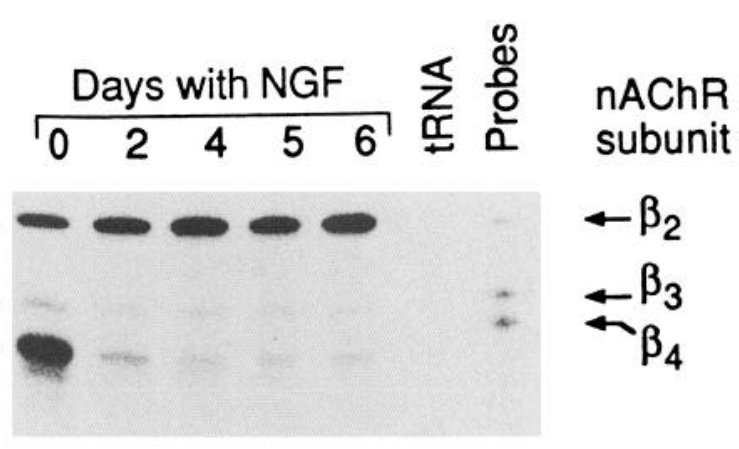

and the $\chi^{2}$ test to assess the significance of differences between the current density distributions.

\section{Results}

$N G F$ alters $n A C h R$ subunit $R N A$ expression

RNA samples were prepared from $\mathrm{PC} 12$ cells that were exposed to $50 \mathrm{ng} / \mathrm{ml}$ of NGF for 1-6 d as described in Materials and Methods. At day 4, one group of cells was returned to culture media not supplemented with NGF. Northern blot analysis of $20 \mu \mathrm{g}$ of total RNA per lane is shown in Figure 1. $\alpha_{3}$ and $\beta_{4}$ RNA decreased within $48 \mathrm{hr}$ of exposure to NGF and decreased only slightly thereafter, but $\beta_{2}$ RNA was observed to increase slowly over the $6 \mathrm{~d}$ period. The removal of NGF from the culture media subsequent to $4 \mathrm{~d}$ of NGF treatment resulted in the rapid return (within $24 \mathrm{hr}$ ) of $\alpha_{3}$ and $\beta_{4}$ RNA to approximately $80 \%$ of the level seen in PC12 cells never exposed to NGF. RNA for $\beta_{2}$ also returned to pre-NGF treatment levels, but in contrast to $\alpha_{3}$ and $\beta_{4}$, this return was gradual over the $3 \mathrm{~d}$ tested. Northern blot analysis of total RNA detects at least two forms of RNA for each subunit as reported previously (see Boulter et al., 1986, 1990). We found that the various transcript forms were altered similarly in response to NGF (see Fig. 1; quantitative data not shown), which suggests that NGF treatment and the regulation of nAChR subunit RNA do not occur through selectively altering the level of one RNA form relative to the other.
The more sensitive method of RNase protection was applied to measure $\alpha_{5}$ and to test for the presence of $\alpha_{2}, \alpha_{4}$, and $\beta_{3}$, which are not observed using Northern blot analysis (Boulter et al., 1990; not shown). This method offers the additional advantage of allowing the simultaneous analysis of more than one $\mathrm{nAChR}$ transcript in an RNA preparation since probes of different lengths can be used. The results of these assays for $\alpha_{2}, \alpha_{3}, \alpha_{4}$, and $\alpha_{5}$ and for $\beta_{2}, \beta_{3}$, and $\beta_{4}$ are shown in Figure 2. As expected from Northern blot analysis, the expression of $\alpha_{3}$ and $\beta_{4}$ decreased rapidly following exposure to NGF and the expression of $\beta_{2}$ increased slowly as seen above. The expression of $\alpha_{5}$ decreased approximately $50 \%$ in response to NGF treatment. No protected species corresponding to $\alpha_{2}$ or $\alpha_{4}$ was detected in PC12 cells. However, a protected species corresponding to $\beta_{3}$ was observed, and the expression of this RNA was decreased subsequent to NGF treatment. These results demonstrate that PC12 cells express RNA corresponding to the nAChR subunits of $\alpha_{3}, \alpha_{5}, \beta_{2}$, $\beta_{3}$, and $\beta_{4}$, but not $\alpha_{2}$ and $\alpha_{4}$, and that the relative concentrations of these RNAs are altered by the presence NGF in the culture medium.

\section{Antisera to neuronal nAChR subunits}

To determine the influence of NGF on the expression of $n A C h R$ subunit protein, we prepared rabbit polyclonal antisera against the putative cytoplasmic domains of the subunits $\alpha_{2}, \alpha_{3}, \alpha_{4}, \alpha_{5}$, 
$\beta_{2}, \beta_{3}$, and $\beta_{4}$, respectively (see Materials and Methods). $\Lambda \mathrm{s}$ shown in Figure 3, Western blot analysis of these bacterially overproduced proteins indicates that each antiserum reacts only with the subunit protein to which it was made. Similarly, ELISA analysis showed that cross-reactivity between sera was not significant unless only low dilutions (less than 1:300) were used (data not shown). There remains the possibility that these sera could react with other subunits, although additional studies indicate that this is not the case. First, overlapping portions of each subunit were used for antigen, and there is essentially no sequence identity between these regions of the receptor subunits. Second, each antibody has been used to study Rat 2 cells that were transfected with either the subunit combination $\alpha_{2} \beta_{2}$ (Rogers et al., 1991a) or $\alpha_{3} \beta_{2}$ (not shown). For the cell line expressing $\alpha_{2} \beta_{2}$, immunoprecipitation and immunocytochemistry were successful only with antisera to $\alpha_{2}$ or $\beta_{2}$ (Rogers et al., 1991a; not shown). Third, antisera to $\alpha_{4}$ or $\beta_{2}$, respectively, immunoprecipitate high-affinity ${ }^{3} \mathrm{H}$-nicotine binding sites from the rat brain. Immunoprecipitation is not altered by preclearing the membrane preparations with $\alpha_{3}, \alpha_{5}, \beta_{3}$, or $\beta_{4}$ receptor subunit antisera, but it can be inhibited by preclearing with either antisera to $\alpha_{4}$ or $\beta_{2}$, respectively (Flores et al., 1992). These results taken together with the results in the next section suggest that the antisera used in this study exhibit subunit specificity.

\section{Immunocytochemistry reveals $P C 12$ cell heterogeneity}

Immunocytochemical analysis of $\mathrm{PC} 12$ cells not treated with NGF or treated for $5 \mathrm{~d}$ is shown in Figure $4 A$ for each antiserum. Immunostaining was observed in PC12 cells for antisera raised to $\alpha_{3}, \alpha_{5}, \beta_{2}$, and $\beta_{4}$. No staining was observed with antisera to either $\alpha_{2}$ or $\alpha_{4}$. Although immunoreactivity toward $\beta_{3}$ is seen, the intensity of this staining varied between experiments. The data in Figure $4 A$ illustrate the point that the treatment of PC12 cells with NGF does not obviously change either the number of cells expressing antigen or the amount of antigen present per cell (see below). As is seen in Figure $4 B$, immunoreactivity toward neuronal nAChR subunits $\alpha_{3}$ and $\beta_{2}$ reveals PC1 2 cell heterogeneity. At least two cell types can be distinguished based upon their relative adherence to the culture surface and their response to NGF. The first group (Fig. 4B) consists of flat cells that attach firmly to the culture dish; they fail to extend neurites in response to NGF, they rarely exhibit immunocytochemical staining, and they do not contain ACh-sensitive currents (see below). The relative abundance of these cells increases with prolonged culture and changes if culture conditions are altered (e.g., reduced serum concentrations or the use of trypsinization for subculture; not shown). In our experiments, these cells represent less than $10 \%$ of the total cell population. The second group of cells are rounded and attach loosely to the dish; they extend neurites in response to NGF, they exhibit immunoreactivity toward neuronal nAChR-directed antisera, and they exhibit ACh-sensitive ion channels (Fig. 4B). Within this group of NGF-responsive PC12 cells, there is consistently observed a subpopulation of cells that appear to be smaller and oval in shape, and to extend shorter neurites (Fig. 4B). They often stain less intensely for $\mathrm{nAChR}$ subunits than do $\mathrm{PC1} 2$ cells that extend extensive neurites. These cell types are also observed in Figure $4 A$.

Antigen appears to concentrate in the cell body (Fig. $4 B$ ). Although staining of neurite-like processes is observed occasionally, the majority remain unstained except for a punctate staining that is observed on some well-developed processes. At present, we are uncertain if this punctate staining reflects clustering of the receptors.

PC12 cells treated with NGF generally cease cell division (Greene and Tischler, 1982; Rudkin et al., 1989), although DNA synthesis and cell division may persist within some cells of the population (Rudkin et al., 1989). To determine if $\mathrm{PCl} 2$ cells that express nAChRs and respond to NGF by altering their morphology also stop cell division, DNA synthesis in PC1 2 cells that were exposed to NGF for varying periods was measured. PC.12 cells were distributed to culture dishes and cultured for $24 \mathrm{hr}$ before adding $50 \mathrm{ng} / \mathrm{ml}$ of NGF for $2,3,4$, and $5 \mathrm{~d}$, respectively. For the final $24 \mathrm{hr}$ of culture, the cells were grown in the presence of $40 \mu \mathrm{M} \mathrm{BUdR}$ (see Materials and Methods) and the nuclei of cells undergoing DNA syntheses were visualized using an antibody to BUdR as described in Materials and Methods. As shown in Figure 5 for PC12 cells cultured without NGF or in the presence of NGF for 2 or $5 \mathrm{~d}$, the nuclei of cells that responded to NGF by extending processes failed to stain for BUdR immunoreactivity. In contrast, the nuclei of PC12 cells that did not extend processes in the presence of NGF stained for BUdR immunoreactivity. This result supports the conclusion that cells in our $\mathrm{PCl} 2$ cell population that fail to respond to NGF and fail to exhibit staining with $\mathrm{nAChR}$ subunit antisera correspond to those that also continue DNA synthesis (see Discussion).

\section{NGF does not alter neuronal nAChR subunit protein expression}

Immunocytochemistry reveals reactivity toward $\mathrm{nAChR}$ subunits $\alpha_{3}, \alpha_{5}, \beta_{2}$, and $\beta_{4}$ in both NGF-treated and untreated PC12 cells. Since there is a dramatic change in the relative mRNA levels of these subunits in response to NGF, we determined if corresponding changes in the protein concentrations of these subunits could be detected through measuring the direct binding of antibody to fixed and permeabilized PC1 2 cells (see Materials and Methods). In three experiments, when binding was calculated by subtracting $\alpha_{2}$ immune binding and the results presented as a ratio to $P C 12$ cells not treated with NGF, no change between the ratio of radioactivity bound by PC1 2 cells for up to $6 \mathrm{~d}$ was detected (Table 1). Similar results were obtained when the binding by preimmune serum was substituted for the binding to antisera to $\alpha_{2}$ (not shown). The amount of binding or antibody to PC12 cells that were not permeabilized with Triton X-100 did not exceed $20 \%$ of the total counts (not shown). This binding probably reflects specific binding to the cytoplasmic domain of nAChR subunits since the immunoreactivity toward tubulin could be visualized in some PC12 cells fixed with $2 \%$ but not 4\% paraformaldehyde (not shown). This result suggests that some membrane permeabilization occurs at the relatively low fixative concentration of $2 \%$ required to preserve immunoreactivity toward the nAChR subunits.

The sensitivity of this assay was determined using the $\alpha_{3}$ subunit. Crude PC12 membranes were prepared (see Rogers et al., 1991a,b), adsorbed against prediluted immune serum (in blocking PBS) overnight at $4^{\circ} \mathrm{C}$, removed by centrifugation, and the supernatant was used for binding assays by radioiodinated antibody to fixed and permeabilized PC12 cells as described in Materials and Methods. Membranes prepared from Rat 2 cultured fibroblasts were used to control adsorption to membranes not containing $\mathrm{nAChRs,}$ and $\alpha_{2}$ immune serum was used to measure background binding (not shown). These assays indi- 
Coomassie Blue Stain

\section{Western Blot}

M.W. (KD)

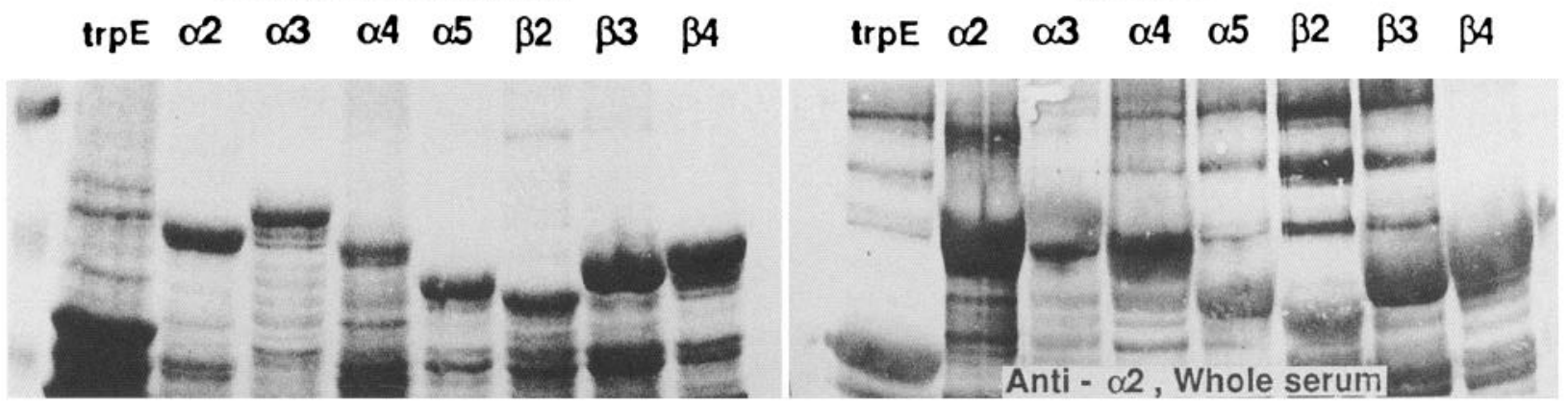

trpE Adsorbed

\section{$\begin{array}{lllllllllllllllll}\operatorname{trpE} & \alpha 2 & \alpha 3 & \alpha 4 & \alpha 5 & \beta 2 & \beta 3 & \beta 4 & & \operatorname{trpE} & \alpha 2 & \alpha 3 & \alpha 4 & \alpha 5 & \beta 2 & \beta 3 & \beta 4\end{array}$}

$75 \cdots$

$50 \cdots$

$39 \ldots$

Anti - $\alpha 2$

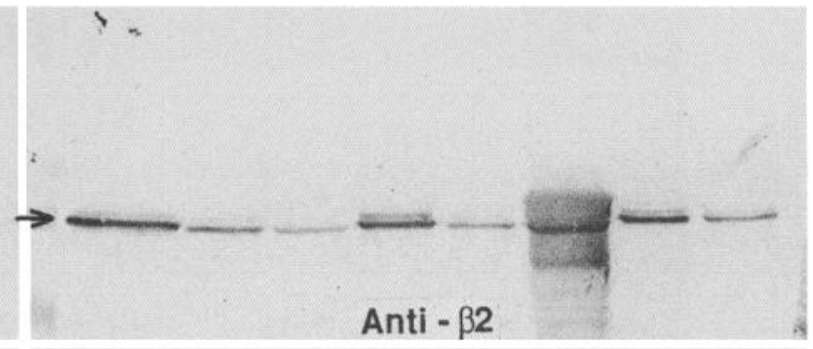

$50 \ldots$

$39 \cdots$

Anti $-\alpha 3$

Anti - $\beta 3$

75 --

$50 \ldots$

39 ...

Anti $-\alpha 4$

Anti - $\beta 4$

75 --

$50 \ldots$

39 -..

Anti $-\alpha 5$

Figure 3. Specificity of antisera raised to neuronal nAChR subunit fusion proteins. At the upper left is shown a Coomassie-stained gel of insoluble protein from $E$. coli strain HBI01 containing either the parent pATH 1 plasmid (trpE) or a fusion construct containing a portion of the cDNA encoding the putative cytoplasmic portion of each nAChR subunit (see Materials and Methods). The upper right panel shows a Western blot of an identical gel visualized using alkaline phosphatase staining after incubation with rabbit anti- $\alpha_{2}$ immune serum diluted 1:3000. In the remaining Western blots, immunoreactivity toward $\operatorname{tr} \mathrm{E}$ and other bacterial proteins was removed from each immune serum. Immunoreactivity to one bacterial protein was not removed in the $\beta_{2}$ antiserum (arrow). Lower molecular weight bands are degradation products of the fusion protein and vary between protein preparations. Prestained molecular weight markers (Bio-Rad), which do not migrate true to their indicated molecular weight in our system, are indicated for the relative comparison of gels. 
cated that the detection sensitivity of our assay is approximately $3 \pm 1$ ng per $10^{6}$ cells (not shown).

\section{$A C h$-activated currents are not altered by NGF treatment}

The above measurements indicate that the relative nAChR subunit protein concentration is not altered in response to NGF treatment despite significant changes in the respective subunit RNA levels. Nevertheless, it is well documented that NGF treatment of $\mathrm{PC} 12$ cells increases $\mathrm{ACh}$-activated currents. To ensure this was true of our PC12 cells and to study further the influence of NGF on expression of functional nAChRs, we used wholecell patch-clamp techniques to compare the current densities and agonist sensitivities of $\mathrm{nAChRs}$ on untreated and NGFtreated PC12 cells. As noted in Materials and Methods, PC12 cells with a flat morphology were found to contain no detectable ACh-activated currents, consistent with immunocytochemical results, and they were not included in the following analysis. Figure 6 shows the ACh current density distribution for $66 \mathrm{PC} 12$ cells that were not treated with NGF. Thirty percent of the cells show ACh sensitivity, and their current densities range from $0.6 \mathrm{pA} / \mathrm{pF}$ to $28.9 \mathrm{pA} / \mathrm{pF}$ with a mean of $4.4 \pm 1.0$. Figure 6 also shows the current distribution for $72 \mathrm{PC1} 2$ cells treated with NGF for 5-7 d. After treatment with NGF, approximately $60 \%$ of the cells respond to $\mathrm{ACh}$ and their current densities range from $0.3 \mathrm{pA} / \mathrm{pF}$ to $28.1 \mathrm{pA} / \mathrm{pF}$ with a mean of $2.9 \pm 0.6$. These results demonstrate that exposure to NGF results in a twofold increase in the proportion (from 30\% to 58\%) of PC12 cells expressing functional $\mathrm{nAChRs}$, but there is little effect on the current density of nAChRs on individual cells.

Recently, Luetje and Patrick (1991) observed that $\alpha_{3} / \beta_{2}$ receptors expressed in Xenopus oocytes were 100-fold less sensitive to the agonist cytisine relative to $\mathrm{ACh}$. In contrast, cytisine was two- to threefold more potent than ACh on the $\alpha_{3} / \beta_{4}$ functional receptor. This observation suggests that cytisine may be used to infer the presence of $\beta_{2}$ or $\beta_{4}$ in functional receptors. An example of a typical response from an ACh-sensitive PC12 cell is shown in Figure 7 for $\mathrm{ACh}$ and cytisine, respectively. The application of agonist causes a rapid inward current that peaks in 100-200 msec after the drug is applied, and the response shows a small degree of desensitization that occurs with a relatively slow time course. We found that cytisine produced a 2.4 \pm 0.3 -fold increase in the evoked current from PC12 cells not exposed to NGF relative to ACh at equal concentrations (see Fig. 7). This result suggests that functional nAChRs on PC12 cells contain the $\beta_{4}$ subunit or that it dominates this pharmacology. Similarly, the cytisine:ACh ratio of receptors on $\mathrm{PC1} 2$ cells treated with NGF is 2.6 , which indicates that treatment with NGF does not alter the relative receptor sensitivity to the two agonists.

\section{Discussion}

In this study, we have analyzed the effect of NGF on the expression of neuronal nAChR subunit RNA, subunit protein, and receptor function. We observed a rapid change in the amount of each nAChR subunit RNA expressed by PC12 cells subsequent to NGF exposure. RNA for $\beta_{2}$ increased slowly over the $6 \mathrm{~d}$ NGF treatment period, but RNA for $\alpha_{3}, \alpha_{5}, \beta_{3}$, and $\beta_{4}$ decreased. This decrease appears to follow three courses: the rapid loss of approximately $75 \%$ of the RNA followed by a slow but continuous loss over the next $5 \mathrm{~d}$ of NGF exposure as observed for $\beta_{4}$, a relatively rapid drop of approximately $50 \%$ followed by a period of essentially no change in the RNA level as observed for the $\alpha_{5}$ and $\beta_{3}$ subunits, and finally the loss of approximately $75 \%$ of the original RNA level over $3 \mathrm{~d}$ of NGF followed by a subsequent period of slow loss as observed for $\alpha_{3}$. These observations suggest that the RNA for each subunit is regulated independently subsequent to NGF exposure, but it is not known if this regulation is transcriptional or posttranscriptional. These differences are also of interest since the genes encoding the nAChR subunits $\alpha_{3}, \alpha_{5}$, and $\beta_{4}$ that are tightly linked (Boulter et al., 1990).

Immunocytochemical staining of PC12 cells was observed for $\alpha_{3}, \alpha_{5}, \beta_{2}, \beta_{3}$, and $\beta_{4}$, but the intensity of staining was particularly strong for $\alpha_{5}$ and $\beta_{2}$. Whether this staining reflects the amount of antigen present or if it is the result of the particular antiserum remains to be determined. Nevertheless, this suggests that the nAChR of PC1 2 cells could be composed of multiple subunits, and the potential for substantial complexity exists. Further, recent reports of additional $\mathrm{nAChR}$ subunits have been made. These subunits include the preliminary reports of $\alpha_{6}$ (Lamar et al., 1990) and the discovery of the $\alpha$-bungarotoxin binding subunits $\alpha_{7}$ and $\alpha_{8}$ from chick (Couturier et al., 1990; Schoepfer et al., 1990). At present, only the chick $\alpha_{7}$-subunit has been reported to have function when introduced into Xenopus oocytes and this receptor is blocked by $\alpha$-bungarotoxin (Couturier et al., 1990). PC1 2 cells also express an $\alpha$-bungarotoxin binding subunit (Patrick and Stallcup, 1977), but the relationship of this subunit to the toxin-binding protein of $\mathrm{PC} 12$ remains unclear since $\alpha$-bungarotoxin does not block $\mathrm{ACh}$ or nicotine-elicited current in these cells (Patrick and Stallcup, 1977; Rogers et al., 1991a). Wc have observed RNA for the rat homolog of $\alpha_{7}$ in our PC12 cells, and the RNA amount is decreased for these species when NGF is added to the culture (D. Johnson, J. Boulter, and S. Rogers, unpublished observation).

In this study, immunocytochemistry and electrophysiology revealed that $\mathrm{nAChR}$ expression in PC12 cells was limited to those cells that responded to NGF by ceasing DNA synthesis and altering their morphology, particularly by extending neurite-

\footnotetext{
Figure 4. Immunocytochemistry of PC12 cells. $A, \mathrm{PC} 12$ cells that were either not treated with NGF or treated for $4 \mathrm{~d}$ were prepared for immunocytochemistry with either preimmune or immune rabbit anti- $\alpha_{2},-\alpha_{3},-\alpha_{4},-\alpha_{5},-\beta_{2},-\beta_{3}$, or $-\beta_{4}$ diluted 1:2000 as described in the Materials and Methods. Immunoreactivity of the preimmune sera toward PC12 cells exposed to NGF was similar to that presented for non-NGF-treated cells and is not shown. Immunoreactivity toward $\alpha_{3}, \alpha_{5}, \beta_{2}, \beta_{3}$, and $\beta_{4}$ is observed, but not toward $\alpha_{2}$ or $\alpha_{4}$. B, Higher magnification of PC12 cells treated with NGF for $4 \mathrm{~d}$ that were stained for immunoreactivity toward nAChR subunit $\alpha_{3}$ or $\beta_{2}$. PC12 cells that extend neurites in response to NGF (double arrows) or are smaller but are poorly attached to the dish surface and become elongated (single solid arrow) exhibit $\alpha_{3}$ and $\beta_{2}$ (double arrows) as well as $\alpha_{5}$ and $\beta_{4}$ (see above) immunoreactivity. Cells that adhere tightly to the culture dish but do not extend neurites in response to NGF fail to show immunoreactivity toward nAChR antisera (arrowheads). A flat cell that is extending neurites and also shows $\alpha_{3}$ immunoreactivity is indicated by the open arrow. Immunoreactivity is seen predominantly in the soma, and it is rarely observed in the extended processes. However, a fine "punctate" pattern of staining can be seen on the processes extended from the cells marked by double arrows. Scale: $A, 10 \mathrm{~mm}=50 \mu \mathrm{m} ; B$, $10 \mathrm{~mm}=12 \mu \mathrm{m}$.
} 


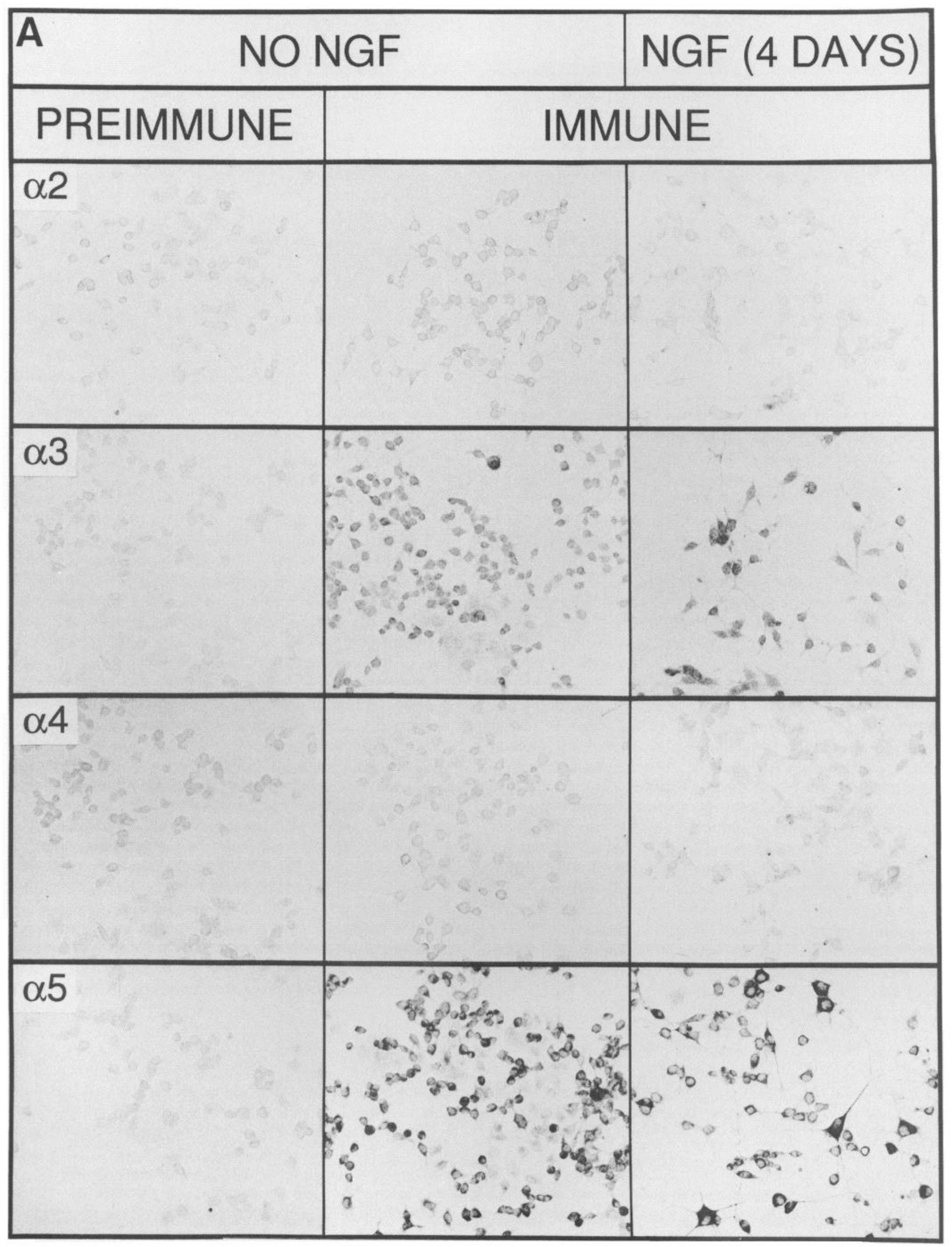




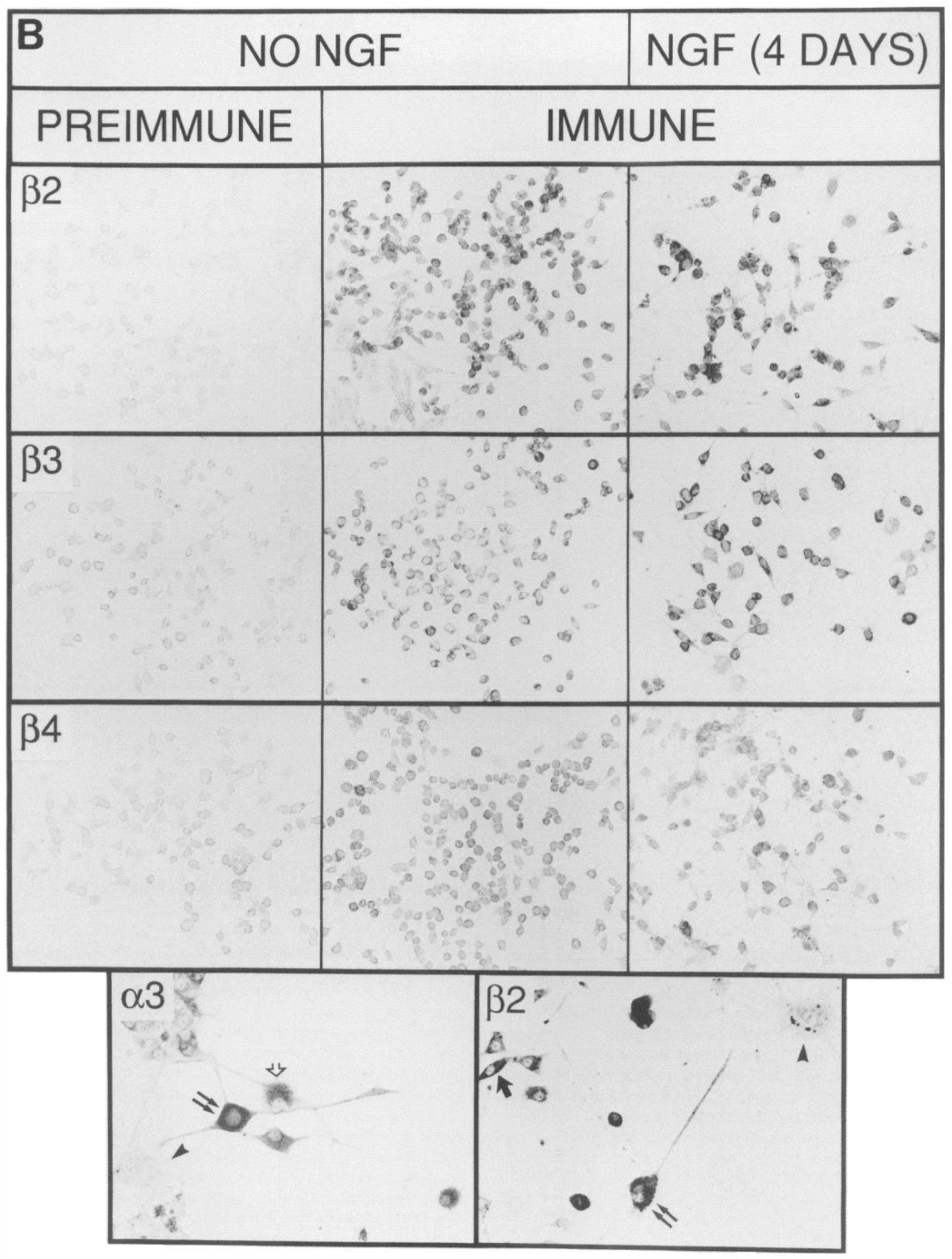




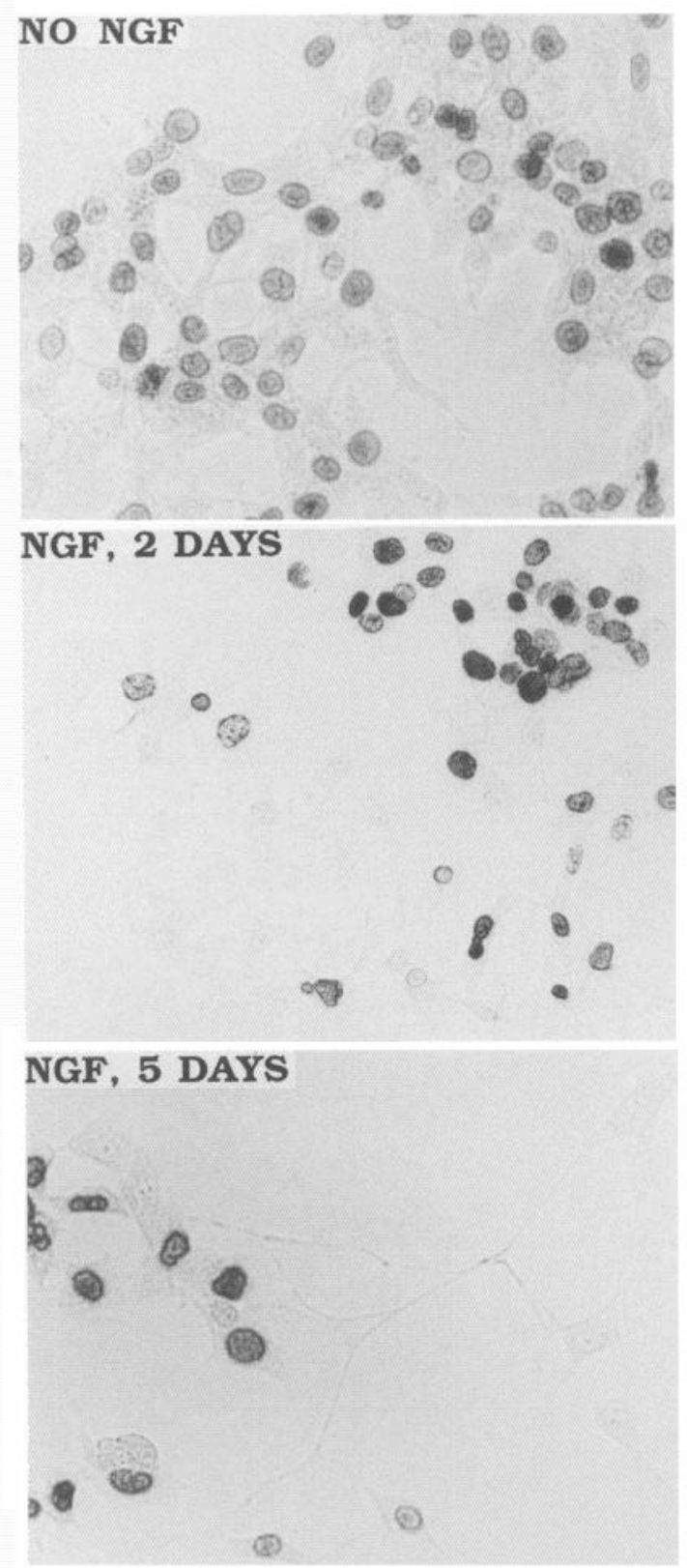

Figure 5. Mouse anti-BUdR was used to visualize BUdR incorporation in to PC12 cells after $4 \mathrm{~d}$ of exposure to NGF. Cells that respond to NGF by extending neurite-like processes do not exhibit BUdR incorporation.

like processes. One consequence of continued cell division by this relatively small subpopulation of cells that do not express nAChRs could be to dilute the relative RNA levels subsequent to NGF treatment. This does not seem to be the case, however, since $\beta_{2}$ RNA increases in the same RNA samples where $\beta_{3}$ and $\beta_{4}$ decrease independently of each other (see Fig. 2). In addition, cell division continues in this subpopulation of PC12 cells throughout the RNA analysis period, yet almost the entire decrease of $\alpha_{3}$ and $\beta_{4}$ RNA occurs within $48 \mathrm{hr}$ of initiating NGF treatment, and then slows substantially thereafter. Finally, upon removal of NGF, the expression of nAChR subunit RNA rapidly returns to approximately $80 \%$ of the pre-NGF treatment value.

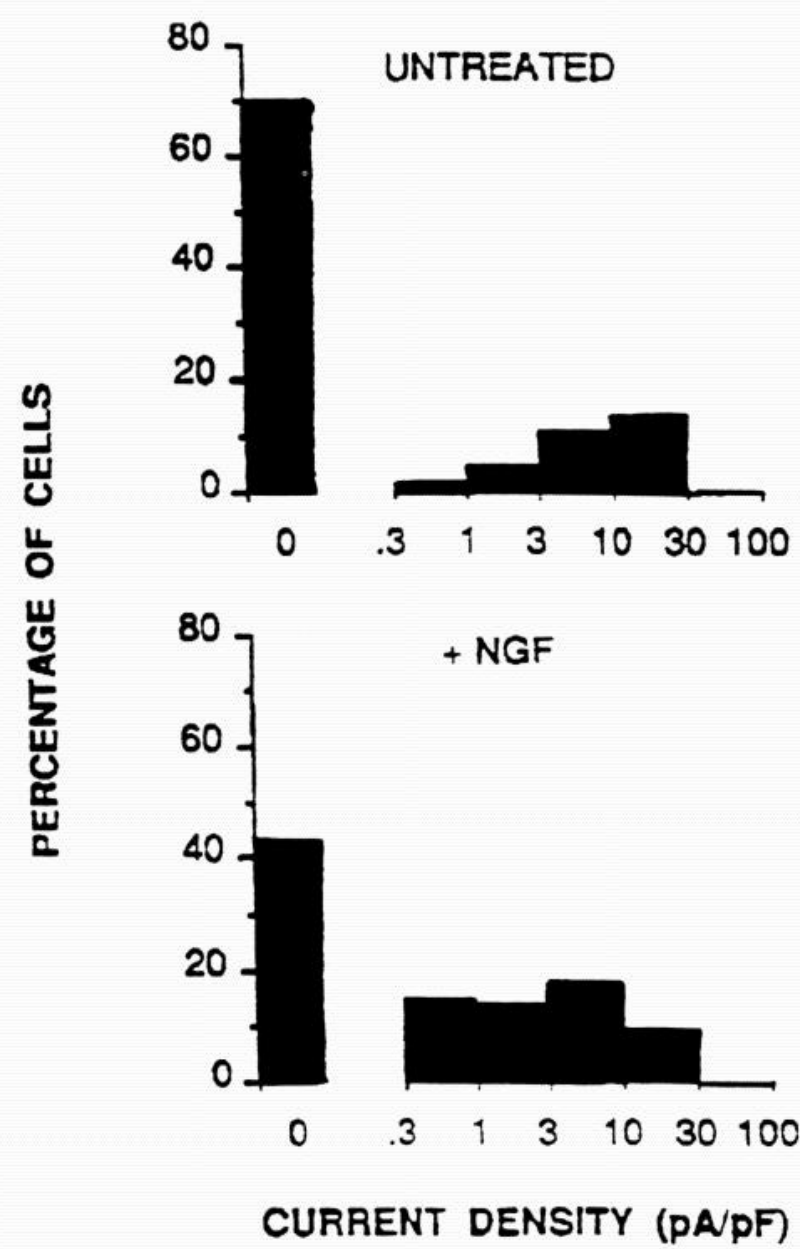

Figure 6. The distribution of ACh current densities for untreated $\mathrm{PC} 12$ cells. In the upper panel is shown the results from $66 \mathrm{PC} 12$ cells. In the lower panel are the results from 72 PC12 cells treated with NGF for 5$7 \mathrm{~d}$. In both cases, $50 \mu \mathrm{M}$ ACh was applied to PC12 cells that were voltage clamped at $-50 \mathrm{mV}$.

Despite substantial changes in the expression of $\mathrm{nAChR}$ subunit RNA, we did not detect corresponding changes in subunit protein, ACh current density, or sensitivity to cytisine. As presented in the results, a threefold change in antigen concentration should be detected by the assays used in this study (not shown). If, for example, the amount of $\alpha_{3}$ or $\beta_{4}$ protein parallels the subunit RNA, then a decrease in the total protein concentration for these subunits subsequent to NGF treatment should reflect the rate of subunit synthesis and degradation. If the synthetic rate remains constant and the degradation rate for the $\mathrm{PC} 12$ receptor is similar to the $20 \mathrm{hr}$ half-life reported for either the nAChRs in muscle prior to innervation (Stanley and Drachman, 1983), in cultured muscle cells (Patrick et al., 1977), or in ciliary ganglia (Jacob et al., 1986), then as little as $5 \%$ of the original receptors at day 0 could be left after $6 \mathrm{~d}$ of NGF treatment. We found that the whole-cell currents and agonist sensitivity of nAChRs on NGF-treated PC12 cells are the same as on nontreated cells (i.e., $\beta_{4}$ containing; see Results). However, since the RNA for most subunits decreases rapidly after NGF exposure, to account for this result either subunit protein synthesis increases, the protein is (or becomes) more stable than assumed, or preexisting receptors become active. 


\begin{tabular}{|c|c|c|c|c|c|c|c|c|}
\hline \multirow{2}{*}{$\begin{array}{l}\text { NGF } \\
\text { (d) }\end{array}$} & \multicolumn{2}{|l|}{$\alpha_{3}$} & \multicolumn{2}{|l|}{$\alpha_{5}$} & \multicolumn{2}{|l|}{$\beta_{2}$} & \multicolumn{2}{|l|}{$\underline{\beta}_{4}$} \\
\hline & $\bar{x}$ & SE & $\bar{x}$ & SE & $\bar{x}$ & SE & $\bar{x}$ & SE \\
\hline 0 & 100 & $\begin{array}{l}- \\
n=7\end{array}$ & 100 & $\begin{array}{l}- \\
n=3\end{array}$ & 100 & $\begin{array}{l}- \\
n=9\end{array}$ & 100 & $\begin{array}{l}- \\
n=3\end{array}$ \\
\hline 1 & 102 & $\begin{array}{c}7.6 \\
n=7\end{array}$ & 137 & $\begin{array}{l}41.0 \\
n=3\end{array}$ & 105 & $\begin{array}{c}5.0 \\
n=9\end{array}$ & 92 & $\begin{array}{l}11.2 \\
n=3\end{array}$ \\
\hline 2 & 103 & $\begin{array}{c}7.6 \\
n=7\end{array}$ & 110 & $\begin{array}{l}24.0 \\
n=3\end{array}$ & 99 & $\begin{array}{c}6.1 \\
n=9\end{array}$ & 82 & $\begin{array}{l}10.6 \\
n=3\end{array}$ \\
\hline 3 & 109 & $\begin{array}{l}14.1 \\
n=4\end{array}$ & 95 & $\begin{array}{l}25.0 \\
n=3\end{array}$ & 99 & $\begin{array}{c}6.3 \\
n=4\end{array}$ & 76 & $\begin{array}{l}19.0 \\
n=3\end{array}$ \\
\hline 4 & 111 & $\begin{array}{l}24.5 \\
n=3\end{array}$ & 124 & $\begin{array}{l}- \\
n=2\end{array}$ & 115 & $\begin{array}{l}23.0 \\
n=3\end{array}$ & 84 & $\begin{array}{l}19.1 \\
n=3\end{array}$ \\
\hline 5 & 94 & $\begin{array}{l}17.9 \\
n=3\end{array}$ & 97 & $\begin{array}{l}- \\
n=2\end{array}$ & 121 & $\begin{array}{l}20.9 \\
n=3\end{array}$ & 75 & $\begin{array}{c}4.0 \\
n=3\end{array}$ \\
\hline
\end{tabular}

Since our antisera are directed to the nAChR subunit cytoplasmic domain and the entire subunit protein pool is measured, our results cannot directly address which of the above possibilities is most likely. However, Lindstrom and colleagues (Whiting et al., 1987) have reported that a $3 \mathrm{~d}$ exposure to NGF induces a sixfold induction of both ${ }^{86} \mathrm{Rb}$ flux and binding $\mathrm{mAb}$ 270 , a monoclonal antibody that binds the $\beta_{2}$ subunit (Whiting et al., 1990) on nonpermeabilized PC12 cells. In our study, we found that NGF treatment increased the proportion of PC12 cells that had ACh currents from $30 \%$ to $60 \%$, and the average current was two- to threefold greater than on untreated cells (although when corrected for cell capacitance, the ACh current density was less). Taken together, these results suggest a fourto sixfold increase in functional nAChRs after NGF treatment. Our observation that $n A C h R$ protein does not detectably change after NGF treatment suggests that the increase in functional receptors on the surface of $\mathrm{PC} 12$ cells could result from a re- distribution of an internal receptor pool. Internal pools of nAChRs have been reported for both muscle nAChRs (e.g., Patrick et al., 1977) and nAChRs in chick ciliary neurons (Jacob et al., 1986). Swanson et al. (1987) and Keyser et al. (1988) have also observed substantial immunoreactivity toward neuronal nAChRs in the soma of neurons from both the CNS and retina, respectively, which is consistent with our observations of the pattern of immunoreactivity in PC12 cells. In any case, since the macroscopic currents and agonist sensitivity were the same before and after NGF treatment, the composition of the newly inserted or possibly activated receptors may be similar to those that are constitutively expressed by non-NGF-treated PC12 cells.

Ifune and Steinbach (1990) observed a five- to sevenfold increase in the median ACh current density of their PC12 cells subsequent to NGF treatment. Although this is not consistent with our results, the heterogeneity among PC12 cells seems to be a likely explanation (see Greene, et al., 1991). The instability
A

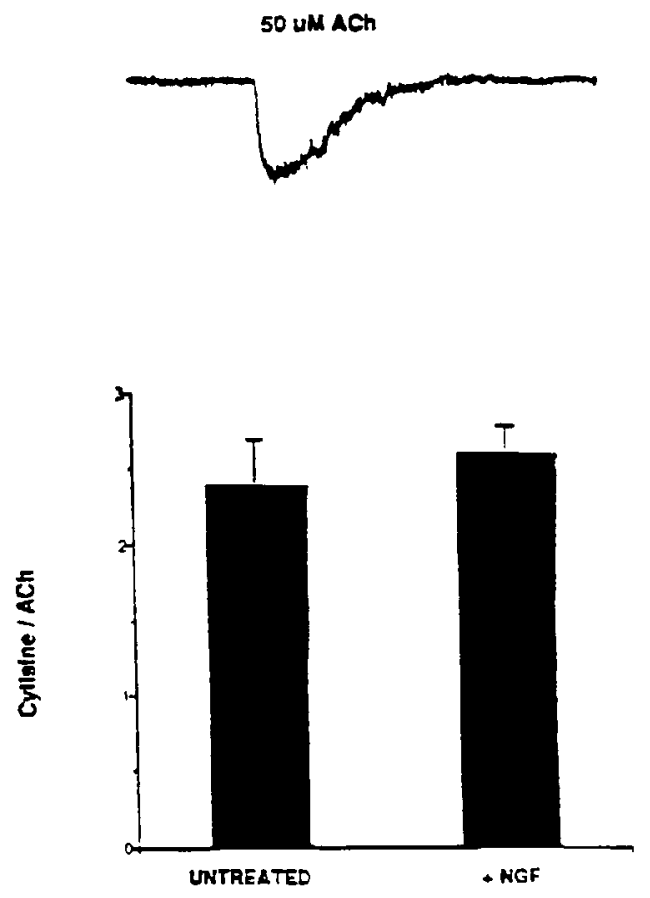

B
50 uM Cylisine

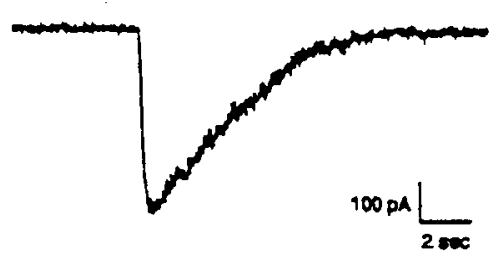

Figure 7. Cytisine:ACh ratio for untreated and NGF-treated PCl 2 cells. In $A$ are shown two current traces from an untreated PC12 cell. The inward currents represent responses to $50 \mu \mathrm{M}$ ACh and $50 \mu \mathrm{M}$ cytisinc, respcctivcly. In $B$ is shown the mean cytisine:ACh ratio for untreated $(n=10)$ and NGF-treated $(n=13)$ PC1 2 cells. There is no significant difference between the ratio of the two groups. The error bars represent the SEM. 
of expression by PC12 cells has been reported elsewhere (Lukas, 1987; Greene, et al., 1991). We have observed that our PC12 cells will lose their ability to express $\mathrm{nAChRs}$ upon prolonged culture, particularly if serum is altered or trypsin-EDTA is used during cell subculture (not shown). Further, it is likely that our PC12 cells vary from those distributed by Greene (Greene and Tischler, 1982; Greene et al., 1991), since our cell division time is around $17 \mathrm{hr}$ whereas the original PC12 cells divided approximately every $3 \mathrm{~d}$. Nevertheless, our PC12 cell line is advantageous for these studics since thcy grow rapidly, they respond robustly to NGF, and the $\mathrm{NAChR}$ phenotype is very stable if great care is taken to ensure standardized culture conditions.

The effect of NGF on $\mathrm{nAChR}$ expression is not unique to PC1 2 cells. We have shown previously that NGF can upregulate the ACh current density on primary sensory neurons in culture (Mandelzys et al., 1990; Mandelzys and Cooper, 1992). When neonatal rat nodose neurons are grown with NGF for 3 weeks and in the absence of other cell types, there is a six- to sevenfold increase in the median $\mathrm{ACh}$ current density compared with sister cultures grown in the absence of NGF. Also, the observation that the regulation of RNA for $\alpha_{3}$ and $\beta_{2}$ occurs in opposite directions has been observed in the animal (Senba et al., 1990). This group found that when facial motor neurons are axotomized, the $\alpha_{3}$ RNA, as measured by in situ hybridization, decreases whereas the $\beta_{2}$ signal is enhanced.

The lack of a correlation between RNA cxpression, subunit protein expression, and the expression of functional receptors is intriguing. Translational or posttranslational regulation of receptor concentration and function is likely to contribute to this process. For example, the regulation of muscle nAChRs occurs both at the level of translation (Horovitz et al., 1989) and posttranslationally through increasing the receptor stability by electrical activity and clustering at the neuromuscular junction (for review, see Salpeter and Loring, 1985). There is also evidence for the role of phosphorylation in altering the number of functional receptors of the closely related neuronal nAChRs in chick ciliary neurons, possibly by altering rates of desensitization (Downing and Role, 1987; Margiotta et al., 1987; Simmons et al., 1990; Vijayaraghaven et al., 1990), and mammalian receptors (see Huganir and Miles, 1989). Therefore, if a substantial surface pool of nAChRs exist that are susceptible to desensitization, then a change in the phosphorylated state could rapidly alter the ratio of active to nonactive receptors. This model can describe the activation of $\mathbf{n A C h R s}$ on receptors present in chick ciliary ganglia (Margiotta et al., 1987), but altering phosphorylation in PC12 cells fails to affect $\mathrm{ACh}$-activated currents (Amy and Bennett, 1983). Further, the increase in the number of surface $\beta_{2}$ subunits (Whiting et al., 1987) collectively favors a model where a receptor pool is recruited as suggested by Jacob et al. (1986) or possibly stabilized in response to NGF treatment. In any case, the composition of $\mathrm{AAChR}$ subunit pool and the function of the receptor would be expected to reflect eventually the change in the RNA observed subsequent to NGF treatment. Of course, the $\mathrm{nAChR}$ subunit RNA may be present in excess of what is required to maintain functional $\mathrm{nAChR}$ expression. Changes in nAChRs that would reflect these possibilities may require a longer period to occur than was studied here, or additional signals such as electrical activity, the presence of agonist, or other trophic factors must be present that are absent in the cultured cell system we employ. Testing these possibilities presents interesting avenues for further study.

\section{References}

Amy CM, Bennett EL (1983) Increased sodium ion conductance through nicotine acetylcholine receptor channels in $\mathrm{PC} 12$ cells exposed to nerve growth factor. J Neurosci 3:1547-1553.

Boulter J, Evans K, Goldman D, Martin G, Treco D, Heinemann S, Patrick J (1986) Isolation of a cDNA clone coding for a possible neuronal nicotinic acetylcholine receptor alpha-subunit. Nature 319: 368-374.

Boulter J, Connolly J, Deneris E, Goldman D, Heinemann S, Patrick J (1987) Functional expression of two neuronal nicotinic acetylcholine receptors from cDNA clones identifies a gene family. Proc Natl Acad Sci USA 84:7763-7767.

Boulter J, O'Shea-Greenfield $\Lambda$, Duvoisin RM, Connolly JG, Wada E, Jensen A, Gardner PD, Ballivet M, Deneris ES, McKinnon D, Heinemann S, Patrick J (1990) $\alpha_{3}, \alpha_{5}$, and $\beta_{4}$ : three members of the rat neuronal nicotinic acetylcholine receptor-related gene family form a gene cluster. J Biol Chem 265:4472-4482.

Chomczynski P, Sacchi N (1987) Single step method of RNA isolation by acid guanidinium thiocyanate-phenol-chloroform extraction. Anal Biochem 162:256-259.

Couturier S, Bertrand D, Matter J-M, Hernandez M-C, Bertrand S, Millar N, Valera S, Barkas T, Ballivet M (1990) A neuronal nicotinic acetylcholine receptor subunit $\left(\alpha_{7}\right)$ is developmentally regulated and forms a homo-oligomeric channel blocked by $\alpha$-BTX. Neuron 5:847856.

Deneris E, Connolly J, Rogers SW, Duvoisin R (1991) Pharmacological and functional diversity of neuronal nicotinic acetylcholine receptors. Trends Pharmacol 12:34-40.

Deneris ES, Connolly J, Boulter J, Wada E, Wada K, Swanson L, Patrick J, Heinemann S (1988a) Primary structure and expression of $\beta_{2}$ : a novel subunit of neuronal nicotinic acetylcholine receptors. Neuron 1:45-54.

Deneris ES, Connolly J, Boulter J, Wada E, Wada K, Swanson L, Patrick $J$, Heinemann $S$ (1988b) $\beta_{3}$ : a new member of nicotinic acetylcholine receptor gene family is expressed in brain. J Biol Chem 265:44724482.

Dichter MA, Tischler AS, Greene LA (1977) Nerve growth factorinduced increase in electrical excitability and acetylcholine sensitivity of a rat pheochromocytoma cell line. Nature 268:501-506.

Dieckmann CL, Tzagoloff A (1985) Assembly of mitochondrial membrane system. J Biol Chem 260:1513-1520.

Downing JEG, Role LW (1987) Activators of protein kinase Cenhance acetylcholine receptor desensitization in sympathetic ganglion neurons. Proc Nall Acad Sci USA 84:7739-7743.

Duvoisin R, Deneris ES, Patrick J, Heinemann S (1989) The functional diversity of neuronal nicotinic acetylcholine receptors is increased by a novel subunit: $\beta_{4}$. Neuron 3:487-496.

Flores CM, Rogers SW, Pabreeza LA, Wolfe BB, Kellar KJ (1992) A subtype of nicotinic cholinergic receptor in rat brain is comprised of $\alpha-4$ and $\beta-2$ subunits and is up-regulated by chronic nicotine treatment. Mol Pharmacol 41:31-37.

Goldman D, Deneris ES, Luyten W, Kochhar A, Patrick J, Heinemann S (1987) Members of a nicotinic acetylcholine receptor gene family are expressed in different regions of the mammalian central nervous system. Cell 48:965-973.

Greene LA, Tischler AS (1982) PC12 pheochromocytoma cell in neurobiology research. Adv Cell Neurobiol 3:373-414.

Greene LA, Sobeth MM, Teng KK (1991) Methodologies for the culture and experimental use of the PC12 rat pheochromocytoma cell line. In: Culturing nerve cells (Banker G, Goslin K, eds), pp 207-226. Cambridge, MA: MIT Press.

Hamill OP, Marty A, Neher E, Sakman B, Sigworth FJ (1981) Improved patch-clamp tcchniqucs for high-rcsolution current recording from cells and cell-free membrane patches. Pfluegers Arch 391:85100.

Harlow E, Lane D, eds (1988) Antibodies: a laboratory manual, pp 335-336. Cold Spring Harbor, NY: Cold Spring Harbor Laboratory.

Horovitz O, Spitsberg V, Salpeter MM (1989) Regulation of acetylcholine receptor synthesis at the level of translation in rat primary muscle cells. J Cell Biol 108:1817-1822.

Huganir RL, Miles K (1989) Protein phosphorylation of nicotinic acetylcholine receptors. Crit Rev Biochem Mol Biol 24:182-215. 
Ifune CK, Steinbach JH (1990) Regulation of sodium currents and acetylcholine responses in PC12 cells. Brain Res 506:243-248.

Jacob MH, Lindstrom JM, Berg DD (1986) Surface and intracellular distribution of a putative neuronal nicotinic acetylcholine receptor. J Cell Biol 103:205-214.

Keyser KT, Hughes TE, Whiting PJ, Lindstrom JM, Karten HJ (1988) Cholinoceptive neurons in the retina of the chick: an immunohistochemical study of the nicotinic acetylcholine receptors. Vis Neurosci 1:349-366.

Krieg PA, Melton DA (1987) In vitro RNA synthesis with SP6 polymerase. Methods Enzymol 155:397-415.

Kyhse-Andersen J (1984) Electroblotting of multiple gels: a simple apparatus without buffer tank for rapid transfer of proteins from polyacrylamide to nitrocellulose. J Biochem Biophys Methods 10: 203-209.

Lamar E, Miller K, Patrick J (1990) Amplification of genomic sequences identifies a new gene, Alpha 6, in the nicotinic acetylcholine receptor gene family. Soc Neurosci Abstr 16:681.

Luetje C, Patrick J (1991) Both $\alpha$-and $\beta$-subunits contribute to the agonist sensitivity of neuronal nicotinic acetylcholine receptors. $J$ Neurosci 11:837-845.

Luetje CW, Wada K, Rogers S, Abramson SN, Tsuji K, Heinemann S, Patrick J (1990) Neurotoxins distinguish between different neuronal nicotinic acetylcholine receptors. J Neurochem 55:632-640.

Lukas R (1987) Phenotypic instability of PC12 cell cultures and approaches toward the identification of nicotinic acetylcholine receptors. Soc Neurosci Abstr 13:795.

Mandelzys A, Cooper E (1992) Effects of ganglionic satellite cells and NGF on the expression of nicotinic acetylcholine currents by rat sensory neurons. J Neurophysiol, in press.

Mandelzys A, Cooper E, Verge VMK, Richardson PM (1990) Nerve growth factor induces functional nicotinic acetylcholine receptors in sensory neurons in culture. Neuroscience 37:523-530.

Margiotta JF, Berg DK, Dionne VE (1987) Cyclic AMP regulates the proportion of functional acetylcholine receptors on chick ciliary ganglion neurons. Proc Natl Acad Sci USA 84:8155-8159.

Papke RL, Heinemann S (1991) The role of the $\beta_{4}$-subunit in determining the kinetic properties of rat neuronal nicotinic acetylcholine $\alpha_{3}$-receptors. J Physiol (Lond) 440:95-112.

Papke RL, Boulter J, Patrick J, Heinemann S (1989) Single-channel currents of rat neuronal nicotinic acetylcholine receptors expressed in Xenopus oocytes. Neuron 3:589-596.

Patrick J, Stallcup W (1977) Alpha-bungarotoxin binding and cholinergic receptor function on a rat sympathetic nerve line. J Biol Chem 252:8629-8633.

Patrick J, McMillian J, Wolfson H, O'Brien JC (1977) Acetylcholine receptor metabolism in a nonfusing muscle cell line. J Biol Chem 252:2143-2153.

Rogers SW, Gahring LC, Papke RL, Heinemann S (1991a) Identifi- cation of cultured cells expressing ligand-gated cationic channels. Protein Expression Purification 2:108-116.

Rogers SW, Hughes TE, Hollmann M, Gasic GP, Deneris ES, Heinemann S (1991b) The characterization and localization of the glutamate receptor subunit GluR 1 in the rat brain. J Neurosci 11:27132724.

Rudkin BB, Lazarovici P, Levi BZ, Abe Y, Fujita K, Guroff G (1989) Cell cycle-specific action of nerve growth factor in PC12 cells: differentiation without proliferation. EMBO J 8:3319-3325.

Salpeter MM, Loring RH (1985) Nicotinic acetylcholine receptors in vertebrate muscle: properties, distribution, and control. Prog Neurobiol 25:297-325.

Schoepfer R, Conroy WG, Whiting P, Gore G, Lindstrom J (1990) Brain $\alpha$-bungarotoxin binding protein cDNAs and $\mathrm{mABs}$ reveal subtypes of this branch of the ligand-gated ion channel gene superfamily. Neuron 5:35-48.

Senba E, Simmons DM, Wada E, Wada K, Swanson LW (1990) RNA levels of neuronal nicotinic acetylcholine receptor subunits are differentially regulated by axotomized facial motoneurons: an in situ hybridization study. Mol Brain Res 8:349-353.

Simmons LK, Schuetze SM, Role LW (1990) Substance P modulates single-channel properties of neuronal nicotinic acetylcholine receptors. Neuron 4:393-403.

Stanley EF, Drachman DB (1983) Rapid degradation of "new" acetylcholine receptors at neuromuscular junctions. Nature 222:67-69.

Swanson LW, Simmons DM, Whiting PJ, Lindstrom J (1987) Immunohistochemical localization of neuronal nicotinic acetylcholine receptors in the rodent central nervous system. J Neurosci 7:33343342.

Vijayaraghaven S, Schmid HA, Halvorsen SW, Berg DK (1990) Cyclic AMP-dependent phosphorylation of a neuronal acetylcholine receptor $\alpha$-type subunit. J Neurosci 10:3255-3262.

Wada E, Wada K, Boulter J, Deneris E, Heinemann S, Patrick J, Swanson $L$ (1989) Distribution of alpha2, alpha3, alpha4, and beta2 neuronal nicotinic receptor subunit mRNAs in the central nervous system: a hybridization histochemical study in rat. J Comp Neuro 284:314-335.

Wada K, Ballivet M, Boulter J, Connolly I, Wada E, Deneris E, Swanson LW, Heinemann S, Patrick J (1988) Functional expression of a new pharmacological subtype of brain nicotinic acetylcholine receptors. Science 240:330-334.

Whiting PJ, Schoepfer R, Swanson LW, Simmons DM, Lindstrom JM (1987) Functional acetylcholine receptor in PC12 cells reacts with a monoclonal antibody to brain nicotinic receptors. Nature 327:515518

Whiting PJ, Schoepfer R, Conroy WG, Gore MJ, Keyser KT, Shimasaki S, Esch F, Lindstrom JM (1991) Expression of nicotinic acetylcholine receptor subtypes in brain and retina. Mol Brain Res 10:61-70. 